\title{
Feasibility Study of Construction Project in Compliance with Bank Investment Supervision Requirements
}

\author{
Jarosław Konior \\ Department of Construction Technology and Management, Faculty of Civil Engineering, Wroctaw University of Science and \\ Technology, Wybrzeże Wyspiańskiego 27, 50-370 Wrocław, Poland
}

\begin{abstract}
On the basis of the 12-year author's practice of bank investment supervision developed methodology significant construction projects risks have been identified and measured: risks of the highest impact values and risks of the biggest likelihood appearance. The research has been recorded in 400-450 reports of 42 investment projects in advanced manufacturing, commercial, residential, hotels and apartment housing sectors. At least one risk of the highest measured level of significance has been highlighted at each phase of investment process: design, construction and maintenance. A reasonable level of risks significance has been determined which stands for not more than $1 / 3$ of possible significance in "risks monitoring" strategy. EPCM (engineering, project and construction management) approach to investment process and solid, consequent, regular construction projects monitoring executed by professional BSI (banking supervision inspector) makes possible to minimise any faults of inappropriate financing of construction projects.
\end{abstract}

Key words: Feasibility study, bank investment supervision, risks significance.

\section{Introduction}

The bank investment supervision/project monitoring services stand for monitoring of a construction project in terms of risks that may occur [1-3] as well as the financial schedule of all works, in order to evaluate the progress of the works in respect of the loan drawdown provisions.

The scope of the services includes:

- Preparation of initial report;

- Preparation of monthly reports;

- Preparation of final report.

The main parties involved in carrying out the construction project are:

- Bank/lender-financial institutions considering a grant of an investment loan to finance the objective investment project;

- Investor/borrower-economic entity acting under the jurisdiction of the laws of Poland which intends to begin the investment project;

Corresponding author: Jarosław Konior, Ph.D., research fields: civil engineering, construction project management, feasibility studies and bank investment supervision.
- Engineer/project monitor-company providing services of technical supervision on behalf of financial consortium, prepared to undertake monitoring of the progress of works during the investment.

\section{Bank Investment Supervision Executive Summary}

The positive assessment of development of the Commercial Centre Project of area 33,500 $\mathrm{m}^{2}$ located in Western Poland has been presented as an example of multi-criteria assessment undergone by a professionally experienced BSI (banking supervision inspector) in a period 2011-12 which was a prerequisite for the financing of the project out of credit funds.

\subsection{Assessment of Project Development for Financing and Implementation}

In order to assess the readiness of the construction project in question for financing and implementation, the employer provided the BSI with the project documents required for the inception report 
preparation.

Below there is an example list of BSI's most significant comments on the Construction Project development and implementation and as well as recommendations to be followed before the financing of the project by the bank started. The project implementation key aspects have been formulated in the most comprehensive and transparent table executive summary table format pinpointing:

- Comments - important project facts presented for the attention of the bank and the investor;

- Recommendations - significant projects defects that must be removed or improved by the following project assessment as not arise cumulative project risks.

\subsection{Final Recommendations on Construction Project Feasibility}

As a result of deep recognition and documented investigation undergone within a process of a bank investment supervision the following final recommendations have been drawn and presented to the bank for the project positive financing release:

(1) The Construction Project has been implemented correctly so far from the technical, legislative and financial aspects;

(2) The Construction Project is sufficiently developed for implementation as far as its technical/design and legislative/formal aspects are concerned, however its safe implementation will require that partial costs and interim dates must be specifically controlled;

(3) The Construction Project is feasible within the assumed budget but BSI points out the identified risks to the project in question presented in Table 1 in the form of comments on the present state and recommendations to be followed in future.

Table 1 List of BSI comments and recommendations on the key aspects of project implementation.

\begin{tabular}{|c|c|c|}
\hline No. & $\begin{array}{l}\text { Project implementation } \\
\text { key aspects }\end{array}$ & Comments and recommendations \\
\hline 1 & line & $\begin{array}{l}\text { Comments: } \\
\text { The design, approvals and opinions are complete and correct in respect of formality and } \\
\text { substance and are consistent with the applicable regulations, in particular with the Polish } \\
\text { Building Law; } \\
\text { The scope of work that makes the subject of the contract with general contractor differs } \\
\text { significantly from the scope that is approved by the valid building permit decisions. An } \\
\text { amended building-permit design is being produced; } \\
\text { The employer does not plan to meet the facility height requirement of the Local Land Use Plan } \\
\text { as part of variations to the building permit design until Stage II, whose implementation will be } \\
\text { postponed. BSI is of the opinion that the assumption that the Local Land Use Plan provisions } \\
\text { will be satisfied in undefined future is risky as it depends on interpretation of the Planning } \\
\text { Authority; } \\
\text { Amended building-permit design has been approved with the building permit decisions which } \\
\text { are final and effective as of the date of this report. } \\
\text { Recommendation: } \\
\text { In view of the introduction of substantial variations to the building permit design and the } \\
\text { detailed design in parallel, particular attention should be paid to a risk associated with the } \\
\text { performance of works that are not the subject of the current building permit decision. BIS } \\
\text { requires that compliance of works execution in relation to terms of possessed decisions will be } \\
\text { confirmed in a form of entries to the site diary by independent licensed engineers i.e. site } \\
\text { manager, supervising inspector and designer being in the office of design author supervision. } \\
\text { The entries should be up to date on the day on the BIS inspection. }\end{array}$ \\
\hline 2 & Decisions and approvals & $\begin{array}{l}\text { Comment: } \\
\text { All decisions, permits, certificates, opinions and approvals issued are complete are valid and } \\
\text { final as well justify the contractor's current operations on the site. } \\
\text { Recommendation: } \\
\text { - It should be ensured that the construction works are performed based on the approved detailed } \\
\text { design, and in particular in compliance with the valid building permit decisions; } \\
\text { After the project has been implemented, service supply/reception agreements need to be } \\
\text { concluded with the service suppliers to the satisfaction of the technical conditions obtained. }\end{array}$ \\
\hline
\end{tabular}


(Table 1 continued)

\begin{tabular}{|c|c|c|}
\hline No. & $\begin{array}{l}\text { roject implementation } \\
\text { ey aspects }\end{array}$ & Comments and recommendations \\
\hline 3 & $\begin{array}{l}\text { Organisational structure } \\
\text { of the project }\end{array}$ & $\begin{array}{l}\text { Comments: } \\
\text { The organisational structure generated defines the relationships among, and the competences } \\
\text { and role of, the Construction Project stakeholders to the degree that is sufficient for a } \\
\text { reasonable implementation of, and accounting for, the project; } \\
\text { The establishing of the post of project manager by the employer ensures that the project will be } \\
\text { managed comprehensively, in particular that its three key elements: circulation of project } \\
\text { documents, a work plan and a critical path as well as costs together with the identification of } \\
\text { additional and substitute work will be controlled. }\end{array}$ \\
\hline 4 & $\begin{array}{l}\text { Cons } \\
\text { contr }\end{array}$ & $\begin{array}{l}\text { - Thements: } \\
\text { - The contract properly defines all the basic activities to be taken by investment process } \\
\text { stakeholders under the Polish Building Law; } \\
\text { The structure of the contract ensures that the Construction Project can be managed efficiently } \\
\text { and that basic project requirements such as time for/date of } \\
\text { completion - quality/implementation standard-price/payment for work can be met; } \\
\text { The interim dates appointed for the handing over of business establishments to tenants ensure } \\
\text { the possibility of making interior decorations in the establishments before the dates of planned } \\
\text { official inspections that are to be carried out as part of the commissioning procedure; } \\
\text { The employer commissioned directly a nominated subcontractor to do demolition work, piling } \\
\text { and preparatory work, including land reclamation, under a separate contract. The contract work } \\
\text { has been completed and accounted for. } \\
\text { Recommendations: } \\
\text { BSI requires that the statements to be made by the general contractor in future include the } \\
\text { names of the subcontractors that have provided services for both of the Joint Venture firms and } \\
\text { also the provision that it has no overdue financial obligations towards subcontractors under the } \\
\text { contracts for implementation of the project in question; } \\
\text { The items of the Unit Price Table need to be adjusted so that the "final discounts" are included } \\
\text { and the final negotiated contract sum is reflected; } \\
\text { As soon as the availability of funds for funding the project is confirmed, the contractor should } \\
\text { be summoned to submit: } \\
\text { - Bank performance guarantee; } \\
\text { - Bank guarantee of retention money. }\end{array}$ \\
\hline 5 & Civil liability ins & $\begin{array}{l}\text { Comment: } \\
\text { The sum insured under every single civil liability insurance taken out by a nominated } \\
\text { subcontractor is lower than that provided for in the contract. } \\
\text { Recommendations: } \\
\text { BSI requires the employer to submit a confirmation that the civil liability insurance policy for a } \\
\text { general contractor has been extended; } \\
\text { BSI requires the investor to submit a confirmation that the insurance policy taken out by a } \\
\text { nominated subcontractor with an agreed insurer has been extended. }\end{array}$ \\
\hline 6 & $\begin{array}{l}\text { Construction risks } \\
\text { insurance }\end{array}$ & $\begin{array}{l}\text { Comments: } \\
\text { The employer has submitted Certificate } 280000011780 / 04 \text { to contract WAUG } 564 / 2009 \\
\text { confirming that the works being done under the contract for the construction of the } \\
\text { Commercial Centre together with technical infrastructure, an accompanying car park and some } \\
\text { landscaping are covered by insurance, with the sum insured being limited to the value of the } \\
\text { works being performed by a general contractor; } \\
\text { The insurance cover, the indemnity amount and ceiling protect the Construction Project against } \\
\text { contingencies generated by random incidents in the works that are performed by a general } \\
\text { contractor only. } \\
\text { Recommendation: } \\
\text { BSI requires the investor to submit an appropriate confirmation that the part of the works on } \\
\text { the project that is to be done by a nominated subcontractor is protected by insurance. }\end{array}$ \\
\hline 7 & \begin{tabular}{|l} 
Professional indemnity \\
insurance and \\
processional \\
authorisations for site \\
inspectors and site \\
manager
\end{tabular} & $\begin{array}{l}\text { Comment: } \\
\text { The employer's supervision inspector and the site manager have the professional qualifications } \\
\text { that are indispensable for performing managerial engineering services in construction, in the } \\
\text { scope defined in the applicable Polish Building Law and covered in the project documents and } \\
\text { have the required professional indemnity insurance taken out in compliance with the civil } \\
\text { liability insurance regulations of Polish Chamber of Civil Engineers. }\end{array}$ \\
\hline
\end{tabular}


(Table 1 continued)

\begin{tabular}{|c|c|c|}
\hline No. & $\begin{array}{l}\text { Project implementation } \\
\text { key aspects }\end{array}$ & Comments and recommendations \\
\hline 8 & Construction schedule & $\begin{array}{l}\text { Comments: } \\
\text { The Construction Work Plan is complete, adjusted to the level of detail of the investors' } \\
\text { schedule; } \\
\text { No critical path can be identified with the construction schedule details; } \\
\text { The Construction Schedule does not allow for the time that is needed for obtaining occupancy } \\
\text { permit referred to in the building permit. } \\
\text { Recommendations: } \\
\text { It is recommended that the Construction Schedule be expanded to a feasible level by allowing } \\
\text { for the time that will be taken by the occupancy permit procedure and by taking into } \\
\text { consideration the milestones referred to in the contract; } \\
\text { Relations among individual project events should be identified and the critical path determined } \\
\text { in order to trace deviations from the path while the Project is being implemented and to assess } \\
\text { risks to meeting the deadline; } \\
\text { The Construction Schedule should be made consistent with the general contractor's report so } \\
\text { that the physical work progress and the progress in accounting for works expenditure can be } \\
\text { revised. }\end{array}$ \\
\hline 9 & Payment plan & $\begin{array}{l}\text { Recommendation: } \\
\text { The advances paid by the employer on the construction works to be done should be accounted } \\
\text { for in a final invoice. BSI notes that the projected value of the final invoice is lower that the } \\
\text { sum of the advances paid. Therefore the parties should settle their accounts well in advance. }\end{array}$ \\
\hline 10 & Environmental issues & $\begin{array}{l}\text { Comments: } \\
\text { The environmental requirements of the consent to the implementation of the project issued are } \\
\text { satisfied in the Building Permit Design and this is accepted without any comments or } \\
\text { reservations; } \\
\text { The employer should take into consideration the fact that it may be placed under an obligation } \\
\text { to follow the environmental impact assessment procedure for the second time while the } \\
\text { building permit amendment procedure planned is being followed. }\end{array}$ \\
\hline 11 & $\begin{array}{l}\text { Land surveying and } \\
\text { environmental analyses }\end{array}$ & $\begin{array}{l}\text { Comments: } \\
\text { After the revision of the project documents and the soil investigation results, it is to be stated } \\
\text { that the design solutions adopted are correct for this type of facility, the existing soil conditions } \\
\text { and the given geotechnical category; } \\
\text { In the light of the investor's submitted results of soil and water specimen tests carried out in a } \\
\text { laboratory BSI states that the reclamation process upgraded the land in question to the group B } \\
\text { quality standards. }\end{array}$ \\
\hline 12 & Project budget & $\begin{array}{l}\text { Comments: } \\
\text { - The Project Budget given in tabular form is presented as a clear breakdown by cost categories; } \\
\text { The Project Budget reflects the up-to-date market indices for construction services, } \\
\text { construction-related services as far as the major items budgeted are concerned, and it is } \\
\text { estimated correctly; however, if the project is to be implemented within the budget, strict } \\
\text { financial discipline needs to be applied, as mentioned above (i.e. the costs generated by } \\
\text { additional and substitute works need to be minimised); } \\
\text { BSI notes that should the cost category limits budgeted be exceeded, the investor is to take into } \\
\text { account the option of using budgetary contingency which have been underestimated compared } \\
\text { to the up-to-date market indices. }\end{array}$ \\
\hline 13 & Investor's own equity & $\begin{array}{l}\text { Comments: } \\
\text { BSI confirms that the VAT invoices and accounting documents listed were submitted by the } \\
\text { investor to BSI for selective verification, together with the documents that had formed the } \\
\text { grounds for issuing them. BSI accepts the invoices submitted and confirms that they match the } \\
\text { construction work done and the serviced delivered and correspond to the scope of the project; } \\
\text { BSI accepts the statement submitted by the employer and takes the value of the employer's } \\
\text { own equity; } \\
\text { BSI confirms the investor's approved own equity constitutes } 30.66 \% \text { of project budget and is } \\
\text { higher than required by bank by } 0.66 \% \text {. }\end{array}$ \\
\hline 14 & $\begin{array}{l}\text { Commercialisation of } \\
\text { the facility }\end{array}$ & $\begin{array}{l}\text { Comment: } \\
\text { Based on the data obtained from the investor BSI states that that rental agreements signed relate to } \\
\text { about } 60 \%\left(19,498 \mathrm{~m}^{2}\right) \text { of the projected rental area of the Commercial Centre. } \\
\text { Recommendation: } \\
\text { BSI requests the investor that monthly reports on the centre commercialisation should be } \\
\text { submitted. }\end{array}$ \\
\hline
\end{tabular}




\section{Bank and Bank Investment Supervision Risks Identification}

On the basis of approach outlined above the following bank investment supervision risks have been identified:

- risks of the highest impact values;

- risks of the biggest likelihood appearance;

- measured and reported by BSI to the bank.

All data have been collected and converted as a result of $[2,3]$ :

- 30-year experience of an author's construction project management;

- 12-year practice of bank investment services, documented in 400-450 BSI reports of 42 construction projects of advanced manufacturing, commercial, residential, hotels and apartment housing sectors.

Entire group of risks has been divided into three groups equivalent to three phases of investment process:

- phase of projects preparation and design works-A;

- phase of projects construction and erection-B;

- phase of projects maintenance and exploitation- $\mathrm{C}$.

for which the most significant risks have been determined [4-7].

\section{Bank Investment Supervision Risks Significance-Conclusions}

All identified risks appearing at entire life-cycle of

Table 2 Risks significance—phase A of projects preparation and design works.

\begin{tabular}{|c|c|c|c|c|}
\hline No. & Significant risks at preparation and design works phase A & $\begin{array}{l}\text { Impact } \\
{[0 ; 1]}\end{array}$ & $\begin{array}{l}\text { Likelihood } \\
{[0 ; 1]}\end{array}$ & $\begin{array}{l}\text { Significance } \\
{[0 ; 1]}\end{array}$ \\
\hline 1 & Delayed agreements and environmental decisions & 1 & 0.3 & 0.30 \\
\hline 2 & $\begin{array}{l}\text { Building permit design non-compliant with an act of building permit design } \\
\text { scope and form }\end{array}$ & 1 & 0.1 & 0.10 \\
\hline 3 & Protest against Building Permit & 1 & 0.1 & 0.10 \\
\hline 4 & Unconfirmed investor's own equity & 1 & 0.2 & 0.20 \\
\hline 5 & Inconsistent administrative building decisions & 0.5 & 0.4 & 0.20 \\
\hline 6 & Irrational procurement process for construction works & 0.2 & 0.1 & 0.02 \\
\hline 7 & Incorrect structured budget for construction works & 0.7 & 0.2 & 0.14 \\
\hline 8 & Unappropriated level of budget contingency & 0.3 & 0.4 & 0.12 \\
\hline 9 & Improperly calculated break - even point of the project & 0.5 & 0.1 & 0.05 \\
\hline 10 & $\begin{array}{l}\text { Unbalance parameters of cost-time-quality within agreement for } \\
\text { construction works }\end{array}$ & 0.6 & 0.2 & 0.12 \\
\hline
\end{tabular}

Table 3 Risks significance - phase B of construction and erection.

\begin{tabular}{|c|c|c|c|c|}
\hline No. & Significant risks at construction and erection phase B & $\begin{array}{l}\text { Impact } \\
{[0 ; 1]}\end{array}$ & $\begin{array}{l}\text { Likelihood } \\
{[0 ; 1]}\end{array}$ & $\begin{array}{l}\text { Significance } \\
{[0 ; 1]}\end{array}$ \\
\hline 1 & Contractors not mobilised for construction works & 0.7 & 0.2 & 0.14 \\
\hline 2 & Not following health \& safety requirements on site & 0.9 & 0.3 & 0.27 \\
\hline 3 & Delays of construction works in comparison to their schedule & 0.6 & 0.4 & 0.24 \\
\hline 4 & Deviation of project budget use in comparison to financial plan & 0.5 & 0.3 & 0.15 \\
\hline 5 & Undisciplined management of additional and substitute construction works & 0.9 & 0,1 & 0.09 \\
\hline 6 & Insufficient supervision of quality and compliance of construction works & 0.8 & 0.3 & 0.24 \\
\hline 7 & $\begin{array}{l}\text { Inadequate design author supervision and classification of significant } \\
\text { changes of design solutions }\end{array}$ & 0.7 & 0.1 & 0.07 \\
\hline 8 & Overstating of monthly quantities of construction works performed & 0.5 & 0.3 & 0.15 \\
\hline 9 & $\begin{array}{l}\text { Insufficient preparation for a building handover by Fire, Sanitary and } \\
\text { Technical Supervision Authorities }\end{array}$ & 0.7 & 0.2 & 0.14 \\
\hline 10 & $\begin{array}{l}\text { Not obtaining operation permit issued by Construction Supervision } \\
\text { Authority }\end{array}$ & 0.9 & 0.1 & 0.09 \\
\hline
\end{tabular}


Table 4 Risks significance - phase $C$ of maintenance and exploitation.

\begin{tabular}{|c|c|c|c|c|}
\hline No. & Significant risks at maintenance and exploitation phase $\mathrm{C}$ & $\begin{array}{l}\text { Impact } \\
{[0 ; 1]}\end{array}$ & $\begin{array}{l}\text { Likelihood } \\
{[0 ; 1]}\end{array}$ & $\begin{array}{l}\text { Significance } \\
{[0 ; 1]}\end{array}$ \\
\hline 1 & $\begin{array}{l}\text { Insufficient commercialisation or production capacity of commercial } \\
\text { investment }\end{array}$ & 1 & 0.3 & 0.3 \\
\hline 2 & Long lasting payback period with delay of break-even point & 1 & 0.2 & 0.2 \\
\hline 3 & Post guarantee handover with many defects for removal or fee reduction & 0.8 & 0.2 & 0.16 \\
\hline 4 & $\begin{array}{l}\text { Retaining of fee in cash or performance bond as a due to poor quality of } \\
\text { construction works after ineffective post guarantee handover }\end{array}$ & 0.8 & 0.2 & 0.16 \\
\hline 5 & $\begin{array}{l}\text { Inappropriate building exploitation not compliant with a building } \\
\text { maintenance book }\end{array}$ & 0.2 & 0.1 & 0.02 \\
\hline
\end{tabular}

construction projects have been presented in Tables 2-4. At least one risk [8-10] of the highest measured level of significance (around 0.3) is highlighted at each phase of investment process:

- Phase A: delayed agreements and environmental decisions;

- Phase B: not following health \& safety requirements on site;

- Phase C: insufficient commercialisation or production capacity of commercial investment.

There are further conclusions drawn from deeper analysis of 400-450 BSI reports elaborated on 42 construction projects:

(1) The above identified risks of investment process have a significant impact (on average 0.65 ) on success of a construction project.

(2) Majority of construction risks appear with likelihood not exceeding the value 0.4 .

(3) Risks of the highest impact values affect the monitored projects with pretty low level of likelihood and those of the lowest impact values are aligned with higher level of likelihood. Lack of correlation of risks impact and their likelihood at really high level determines reasonable level of risks significance, not higher than $1 / 3$ of possible significance in "risks monitoring" strategy [8-10]. Therefore, all professionally monitored construction risks are "manageable".

(4) EPCM (engineering, project and construction management) approach to investment process and solid, consequent, regular construction projects monitoring executed by professional BSI make possible to minimise any faults of inappropriate financing of construction projects.

\section{References}

[1] Kapliński, O., and Konior, J. 2007. "Analytical Methods and Models in the Building Project Engineering." PAN multi-author monography: 249-84.

[2] Konior, J. 2015. "Random and Fuzzy Measure of Unpredictable Construction Works." Archives of Civil Engineering, PAN LXI: 75-87.

[3] Konior, J. 2015. "Enterprises Risk Assessment of Complex Construction Projects." Archives of Civil Engineering, PAN LXI: 63-74.

[4] Zavadskas, E. K., Turskisb, Z., and Tamošaitienec, J. 2010. "Risk Assessment of Construction Projects." Journal of Civil Engineering and Management 16 (1): $33-46$.

[5] Mak, S., and Picken, D. 2000. "Using Risk Analysis to Determine Construction Project Contingencies." Journal of Construction Engineering and Management 126 (2): 130-6.

[6] Ibadov, N., and Kulejewski, J. 2014. "The Assessment of Construction Project Risks with the Use of Fuzzy Sets Theory." Technical Transactions, Cracow University of Technology 111 (1-B): 175-82.

[7] Skorupka, D. 2008. "Identification and Initial Risk Assessment of Construction Projects in Poland.” Journal of Management in Engineering 24 (3): 120-7.

[8] Smith, N. J., Merna, T., and Jobling, P. 2009. Managing Risk in Construction Projects. Oxford, UK: Wiley-Blackwell.

[9] Almeida, N. M., Sousa, V., Dias, L. A., and Branco, F. 2015. "Engineering Risk Management in Performance-based Building environments." Journal of Civil Engineering and Management 21 (2): 218-30.

[10] Silvestre, J. D., Silva, A., and de Brito, J. 2015. 
"Uncertainty Modelling of Service Life and

Environmental Performance to Reduce Risk in Building
Design Decisions." Journal of Civil Engineering and Management 21 (3): 308-22. 